\title{
SEL1L3 wt Allele
}

National Cancer Institute

\section{Source}

National Cancer Institute. SEL1L3 wt Allele. NCI Thesaurus. Code C150058.

Human SEL1L3 wild-type allele is located in the vicinity of 4p15.2 and is approximately $142 \mathrm{~kb}$ in length. This allele, which encodes protein sel- 1 homolog 3 protein, may be involved in signal transduction and calcium binding. 